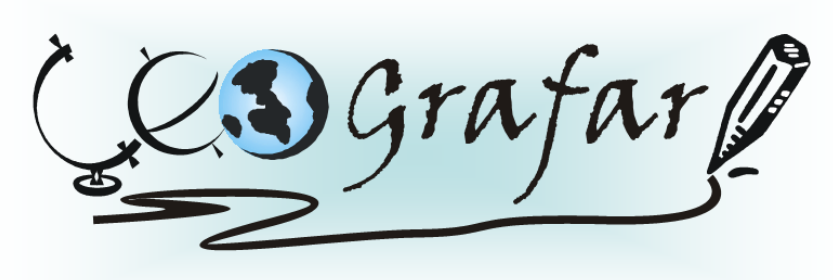

Revista Eletrônica do Programa de Pós-Graduação em Geografia - UFPR

\title{
CARACTERÍSTICAS E CONTRADIÇÕES DAS CIDADES NO CONTEXTO DO AGRONEGÓCIO: UMA ANÁLISE DAS CIDADES DE SAPEZAL (MT) E CHAPADÃO DO SUL (MS)
}

\author{
CONTRADICTIONS AND CONTRADICTIONS OF CITIES IN THE CONTEXT OF THE \\ AGRIBUSINESS: AN ANALYSIS OF THE CITIES OF SAPEZAL (MT) \\ AND CHAPADÃO DO SUL (MS)
}

(Recebido em 21-06-2016; Aceito em: 26-01-2017)

Danilo Souza Melo

Mestre em Geografia pela Universidade Federal de Mato Grosso do Sul - UFMS danilosouza.geo@hotmail.com

\section{Resumo}

O processo de ocupação do antigo Mato Grosso promovido pelo Estado resultou na transferência de grandes quantidades de terras para capitalistas que posteriormente fundaram núcleos urbanos para dar suporte à venda de terras. Alguns destes núcleos ganharam destaque pelo grande crescimento econômico resultante do agronegócio, estas cidades passaram a ser chamadas por alguns pesquisadores de "Cidades do Agronegócio". Este trabalho tem como objetivo discutir as características e contradições resultantes da reprodução da agricultura capitalista nas cidades de Sapezal (MT) e Chapadão do Sul (MS) no contexto das chamadas cidades do agronegócio. Para tanto, utilizamos uma metodologia baseada em revisão bibliográfica, analise de dados estatísticos e trabalhos de campo com a utilização de entrevistas. Neste trabalho foi possível compreender que a cidade e 0 campo compõem um território do capital, no qual, intensas contradições são resultantes do seu desenvolvimento. ${ }^{1}$

Palavras-Chave: Cidades do Agronegócio; Contradições; Sapezal (MT); Chapadão do Sul (MS); Agricultura Capitalista.

\footnotetext{
${ }^{1}$ Este trabalho apresenta resultados de trabalhos de campo da pesquisa de mestrado intitulada: Geografia das ocupações e manifestações em Mato Grosso e Mato Grosso do Sul (2000 - 2012).
} 


\begin{abstract}
The process of occupation of old Mato Grosso promoted by the State resulted in the transfer of great amounts of lands for capitalists that later founded urban nuclei for sale to give support of lands. Some of these nuclei won prominence for the great economical growth resulting from the Agribusiness, these cities passed to be called by some researchers of "Cities of Agribusiness." This work has as objective discusses the characteristics and resulting contradictions of the reproduction of the capitalist agriculture in the cities of Sapezal (MT) and Chapadão do Sul (MS) in the context of the calls cities of the Agribusiness. For so much, we used a methodology based in bibliographical revision, analyze of statistical data and field works with the use of interviews. In this work it was possible to understand that the city and the field compose a territory of the capital, in which, intense contradictions are resultants of his/her development.
\end{abstract}

Keysword: Cities of Agribusiness; Contradictions; Sapezal (MT); Chapadao do Sul (MS); Agriculture Capitalist.

\title{
Introdução
}

Os estados de Mato Grosso e Mato Grosso do Sul são comumente associados à agricultura capitalista, principalmente pela expressiva produção de commodities (soja e cana-de-açúcar) e pecuária. Este modelo produtivo presente no campo brasileiro também conhecido como Agronegócio é resultado de mudanças na base técnica produtiva no campo proporcionadas pela Revolução Verde na década de 1970 e por ações do Estado brasileiro. Segundo Leite (2012, p.82) "No Brasil, o vocábulo agribusiness foi traduzido inicialmente pelas expressões agroindústria e complexo agroindustrial, que buscavam ressaltar a novidade do processo de modernização e industrialização da agricultura, que se intensificou nos anos 1970."

A formação da grande propriedade em MT e MS por meio de leis e decretos, e, o "novo" modelo de agricultura capitalista (Agronegócio) impulsionado pela Revolução Verde, promoveram 0 surgimento de núcleos urbanos especializados neste modelo produtivo, aqui chamados de Cidades do Agronegócio², termo utilizado por Elias (2003). Para Elias "[...] a cidade do agronegócio é aquela cujas funções de atendimento às demandas do agronegócio globalizado são hegemônicas sobre as demais funções." (ELIAS; PEQUENO, 2007: 30).

Nessa perspectiva, alguns municípios destacam-se pela forte presença do agronegócio, principalmente em seu núcleo urbano, como é o caso de Sapezal (MT), presente entre os maiores produtoras de soja do país (IBGE, 2010), e Chapadão do Sul (MS), símbolo sulmatogrossense do agronegócio.

\footnotetext{
2 Não objetivamos discutir aqui o conceito de Cidades do Agronegócio, mas sim, a dinâmica e as contradições presentes nas cidades estudadas.
} 
Objetivamos neste artigo discutir as características e contradições resultantes da reprodução da agricultura capitalista nas cidades de Sapezal (MT) e Chapadão do Sul (MS) no contexto das chamadas cidades do agronegócio.

\section{Procedimentos metodológicos}

Para cumprir com o objetivo, adotamos diferentes procedimentos metodológicos, que passam pela revisão bibliográfica sobre o assunto, sistematização de dados estatísticos, trabalho de campo e a utilização de fontes orais. Essa diversidade na metodologia forneceu diferentes informações que se complementam e que buscamos analisar.

A pesquisa se iniciou com a revisão bibliográfica sobre a origem dos municípios e 0 processo de apropriação capitalista da terra nos estados de Mato Grosso e Mato Grosso do Sul. Esse procedimento nos permitiu compreender a complexidade da formação da estrutura fundiária dos estados e do surgimento de núcleos urbanos voltados à dinâmica da agricultura capitalista.

Encontramos nos dados estatísticos do Instituto Brasileiro de Geografia e Estatística (IBGE), principalmente nas pesquisas do Censo Agropecuário de 2006 e Relatório de Produção Agrícola Municipal (PAM) de 2010 importantes informações que subsidiaram este trabalho. Essas informações foram sistematizadas e resultaram na construção de quadros e tabelas discutidas aqui.

Subsidiados por todas essas informações, realizamos trabalhos de campo nos municípios estudados, no qual realizamos entrevistas com moradores, trabalhadores e representantes do poder público. Ainda em campo registramos por meio de fotos as principais características dos núcleos urbanos.

Desta maneira, a metodologia utilizada permitiu esta breve análise sobre as características e contradições resultantes da reprodução da agricultura capitalista nas cidades de Sapezal (MT) e Chapadão do Sul (MS).

\section{Resultados e discussões: A colonização em Mato Grosso e Mato Grosso do Sul}

A origem destes núcleos urbanos de Sapezal e Chapadão do Sul, posteriormente tornados municípios, está nos projetos de colonização privados realizados entre 1950 e 1970, como pretexto para a transferência de grandes extensões de terra para empresários.

Destacamos, também, a colonização dirigida pelo Estado, iniciada, em 1938, durante 0 governo Vargas, via "Marcha para o Oeste", com o objetivo de amenizar os problemas sociais no Sul e Sudeste: "Ao mesmo tempo, contribuía para preservar a antiga estrutura agrária nacional e esvaziar a 
discussão em torno da Reforma Agrária, ao conduzir os trabalhadores rurais sem-terra e/ou expropriados para as terras de ninguém." (ABREU, 2001: 62).

No entanto, não eram "terras de ninguém" como afirmou Abreu (2001), a colonização oficial avançou principalmente sobre terras indígenas expropriando-os.

Ao basear-se nessas preocupações, a política de colonização oficial orientouse principalmente no sentido de criar condições para a instalação de famílias de trabalhadores rurais em áreas de terras indígenas e devolutas. Mas sempre com o objetivo de reduzir as "tensões sociais" nas áreas de "superpopulação" e, ao mesmo tempo, criar condições para 0 desenvolvimento capitalista em "terras virgens", com a formação de mercados, criação de novas atividades econômicas etc. (IANNI, 1979: 59)

A Colônia Agrícola Nacional de Dourados (CAND), Taquari-Mirim e Ministro João Alberto (Nova Xavantina) foram criadas em 1948, a partir da lógica expansionista do Estado. Todavia, "nessa região, o governo assentou os colonos na terra, esperando que a tornassem produtiva, ainda que sem estrutura para tal. No entanto, transformá-la em terra fértil e permanecer na área sem as condições mínimas necessárias constituía o grande desafio" (PICOLI, 2006: 59).

A Colônia Nacional Agrícola de Dourados (CAND) atraiu camponeses ${ }^{3}$ sem-terra de todo 0 país, assim como capitalistas interessados na revenda dos lotes. Foram destinados 300.000 hectares para a implantação da Colônia, distribuídos em lotes de 50 hectares, mas, segundo Naglis (2007), a CAND possuía uma área excedente ao tamanho oficial, pelo qual, trabalhadores sem-terra disputaram sua posse.

A colonização privada iniciou-se a partir de 1947, voltando-se para o Norte do espaço matogrossense. O governador Arnaldo Estevão de Figueiredo, favorável à aquisição de grandes extensões de terras por particulares para promover a colonização, levantava a necessidade de reformulação na legislação vigente sobre terras (MORENO, 1994). Criou-se, assim, em 1947, um conjunto de leis ${ }^{4}$ extremamente liberal, regulando 0 arrendamento, as medições e demarcações de terras devolutas e a aquisição gratuita de terras ocupadas, até serem consolidadas no Código de Terras de 1949 (MORENO, 2008). Convém frisar que essa legislação permitiu a regularização de posses após a Lei de Terras de 1850 e Lei Estadual de 1927, regularizando grandes ocupações irregulares há quase cem anos!

\footnotetext{
${ }^{3}$ Sobre o campesinato na CAND indicamos a leitura de: MOTTA, Regina Célia C. de S. As linhas da campesinidade na (in)subordinação camponesa em Glória de Dourados - MS. 2013. 244p. Dissertação (Mestrado em Geografia) Universidade Federal da Grande Dourados.

4 "Lei n. 18, de 21 de outubro de 1947, a Lei n. 68, de 11 de dezembro de 1947, e a Lei n. 75, de 12 de dezembro" (MORENO, 1994: 184).
} 
Este conjunto de leis criadas em 1947, possibilitou, também, a transferência de terras para particulares:

Embora tais contratos repassassem áreas de até um milhão de hectares, sob a única condição de os colonizadores assentarem gratuitamente em 50 lotes de até 50 hectares pelo menos 500 famílias de imigrantes, o que significava destinar apenas 2.500 hectares do total recebido, o empreendimento particular revelou ser mais uma negociata. (MORENO, 1994: 139)

Havia o agravante de capitalistas se passarem por colonizadores para lucrarem na compra e venda das terras destinadas à colonização o que, já em 1925, tornava a situação insustentável, pois: "[...] muitos concessionários se tornaram inadimplentes, não cumpriram as cláusulas contratuais e incorporaram as terras concedidas ao patrimônio particular, para, depois, negociar ou explorar em benefício próprio" (MORENO, 1994: 139).

A maioria dos projetos privados de colonização se localizam no Mato Grosso, principalmente na área da rodovia Cuiabá-Santarém. As áreas da Idesco e da Sinop constituem mini-Estados sob domínio dos colonizadores, que se assemelham a barões feudais, fiéis, contudo, ao governo federal. (BECKER, 1994: 37)

A expansão da fronteira agrícola capitalista, impulsionada na década de 1970, incentivada pelo Estado, impulsionou a venda de terras, acelerando a criação de centros urbanos e possibilitando a comercialização de terras na área rural. Empresas como a Colonizadora da Sociedade Imobiliária Noroeste do Paraná/SA (SINOP), a Colonizadora Agropecuária Mutum, entre outras, deram seus nomes aos novos municípios. As cidades serviram de ponto de apoio à comercialização de terras efetuada pelas companhias imobiliárias.

Os projetos de colonização promovidos por empresas particulares foram em número superior a 50 , sendo que, nestes, se fixaram a maior parte dos migrantes, que ganharam vastas áreas de terras, e em poucos anos foram criados vários novos municípios em cada projeto. (PICOLI, 2006: 57)

Algumas áreas adquiridas por empresas colonizadoras promoveram o loteamento das áreas rurais e fundaram cidades. Muitas dessas cidades tornaram-se prósperas nos últimos anos, principalmente as atreladas ao processo de modernização do campo e às culturas de exportação, como a soja, inclusive recebendo a alcunha de "cidades do agronegócio". Todavia, as contradições presentes nessas cidades revelam o lado perverso desse modelo produtivo. Logo, existe relação intrínseca entre a colonização e formação de núcleos urbanos especializados na agricultura capitalista 
em Mato Grosso e Mato Grosso do Sul, seja pelas condições do processo de colonização em detrimento dos povos tradicionais ou, então, pela legislação fundiária que legalmente sustenta a concentração de terras e a disseminação dos princípios da modernização do campo.

\section{Cidade do agronegócio?}

O modelo de agricultura capitalista também conhecido como Agronegócio surge a partir da década de 1970, com o processo de globalização, principalmente do capital, no qual, parte da agricultura brasileira sofreu intensas transformações tanto no processo produtivo quanto em sua racionalidade. O processo produtivo alterou-se pelo uso de novas técnicas e tecnologias na agricultura, aliados ao discurso de produtividade e de modernidade derivados da chamada Revolução Verde. Pereira (2012: 687) afirma:

A Revolução Verde foi concebida como um pacote tecnológico - insumos químicos, sementes de laboratório, irrigação, mecanização, grandes extensões de terra - conjugado ao difusionismo tecnológico, bem como a uma base ideológica de valorização do progresso. Esse processo vinha sendo gestado desde o século XIX, e, no século XX, passou a se caracterizar como uma ruptura com a história da agricultura.

O combate ao problema da fome e miséria no mundo, intensificada no final da Segunda Guerra Mundial (1939 - 1945), foi o principal argumento sustentador da Revolução Verde. Idealizada no uso da tecnologia para aumentar a produtividade e, consequentemente, eliminar a fome mundial, esta chamada "revolução", além de não resolver os problemas da fome, também não colocou em discussão os problemas sociais causados pelo modelo socioeconômico:

Pouco a pouco, a ideia de que a fome e a miséria são um problema social, político e cultural vai sendo deslocada para o campo técnico-científico, como se este estivesse à margem das relações sociais e de poder que se constituem, inclusive, por meio das técnicas. (PORTO-GONÇALVES, 2004: 213)

A base técnica não foi à única mudança na agricultura, intensificou-se, ou melhor, imprimiu-se uma lógica e racionalidade no campo, por meio de novas técnicas e tecnologias. A Revolução Verde originou um novo modelo de agricultura capitalista, o agronegócio. $O$ novo, na realidade, representa a velha estrutura baseada no latifúndio monocultor de produção e exportação de commodities, aliada à nova base técnica, ao capital financeiro sustentado na mediação do Estado (OLIVEIRA, 2001). 
De acordo com Oliveira (2001: 186):

A chamada modernização da agricultura não vai atuar no sentido da transformação dos latifundiários em empresários capitalistas, mas, ao contrário, transformou os capitalistas industriais e urbanos - sobretudo do Centro-Sul do país - em proprietários de terra, em latifundiários. A política de incentivos fiscais da Sudene e da Sudam foram os instrumentos de política econômica que viabilizaram esta fusão. Dessa forma, os capitalistas urbanos tornaram-se os maiores proprietários de terra no Brasil, possuindo áreas com dimensões nunca registradas na história da humanidade.

Para Fabrini e Roos (2014) o Agronegócio e latifúndio coexistem como partes de uma totalidade do modo de produção capitalista possuindo objetivos em comum, dentre eles, a extração da renda da terra. Portanto:

Agronegócio e latifúndio estão unidos pela acumulação capitalista rentista e a produção agropecuária (mercadorias) não está colocada no centro do processo para ambos os segmentos. Enfim, o Brasil é mais latifundiário do que se pensa. (FABRINI e ROSS, 2014: 27)

$\mathrm{Na}$ intensificação da agricultura capitalista no campo brasileiro, núcleos urbanos se especializaram de acordo com o modelo produtivo no campo. Santos (1996) em A Urbanização Brasileira denomina estes núcleos urbanos como cidades do campo. Baseada nos escritos de Santos, Denise Elias cunha o termo cidades do agronegócio, segundo Elias (2003):

Quanto mais se difunde o agronegócio globalizado, mais urbana se torna a sua regulação, e se produzem cidades do agronegócio, que passam a desempenhar novas funções, transformando-se em lugares de todas as formas de cooperação erigidas pelo agronegócio globalizado e resultando em muitas novas territorialidades. Se a cidade é a materialização das condições gerais de reprodução do capital (CARLOS, 2004), a cidade do agronegócio é aquela cujas funções de atendimento às demandas do agronegócio globalizado são hegemônicas sobre as demais funções. (2003: 30)

As cidades "do" agronegócio segundo Elias (2012) compõem parte da chamada Região Produtiva Agrícola (RPA):

A RPA é resultado do impacto das forças externas/modernizantes e a capacidade de suas virtualidades, lugar funcional das redes agroindustriais globalizadas. Como objeto e sujeito da economia globalizada, é um espaço que nada mais tem de autônomo, não se fechando sobre si mesmo, de forma independente do restante do mundo, com o qual interage permanentemente 
para a renovação tecnológica, para a complementação da produção e, em última instância, para a acumulação ampliada do capital do agronegócio. (ELIAS, 2012: 05)

Os núcleos urbanos presentes nas RPA's se especializaram em atender as novas demandas do campo, estruturando-se, assim,

A produção agrícola e agroindustrial intensiva exige que os espaços urbanos próximos ao espaço agrícola racionalizado se adaptem para atender às suas principais demandas, em virtude de fornecerem parte dos aportes técnicos, financeiros, jurídicos, de mão-de-obra e de todos os demais produtos e serviços necessários à sua realização. (ELIAS, 2012: 07)

Em seu estudo, Silva (2007) dissertou sobre o conjunto de municípios que possuem traços comuns, criados para atender às necessidades do agronegócio em Mato Grosso. A esse conjunto, denominou de família de municípios $^{5}$, formados para serem lócus de atuação do agronegócio:

Para Silva:

Existiria uma família de municípios do agronegócio no Mato Grosso (no front, de modo geral), que diz respeito a um conjunto de municípios novos ou antigos com infraestruturas novas, ambos originados como resposta às solicitações do mercado para uma produção agrícola moderna, sendo esta determinante na dinâmica econômica desses municípios (2007: 17-18)

Estas cidades são parte importante do processo de desenvolvimento do capitalismo no campo, por possuírem dinâmicas voltadas para o agronegócio. As cidades surgidas ou especializadas no agronegócio, também chamadas "Cidades do Agronegócio", apresentam infraestrutura necessária para esse modelo produtivo. A "cidade tornou-se o lócus principal da produção, pois é nela que se concentram os principais serviços, produtos e agentes (trabalhadores agrícolas, produtores, consultores, empresas, bancos) necessários à produção" (FREDERICO, 2011: 7).

Todavia, entendemos que as cidades não pertencem ao agronegócio, estas são projetadas e organizadas para capitalistas e para a (re)produção do capital apresentando assim intensas desigualdades e conflitos. Nesse sentido, Beltrão Spósito (2004) afirma que:

A cidade é, particularmente, o melhor lugar onde se reúnem as melhores condições para o desenvolvimento do capitalismo. 0 seu caráter de concentração e densidade viabiliza a realização com maior rapidez do ciclo do capital, ou seja, diminui o tempo entre o primeiro investimento necessário à realização de uma determinada produção e 0 consumo do produto. A cidade reúne qualitativa e quantitativamente as

\footnotetext{
${ }^{5}$ SILVA, S. C. A família de municípios do agronegócio: expressão da especialização produtiva no front agrícola. Dissertação (Mestrado em Geografia) UNICAMP - Campinas- SP, 2007.
} 
condições necessárias ao desenvolvimento do capitalismo, e por isso ocupa o papel de comando na divisão social do trabalho. (2004: 64)

O agronegócio, como parte do modo capitalista de produção, atua em todo território brasileiro, abrangendo o campo e a cidade, como nas cidades especializadas no agronegócio.

No agronegócio a configuração do circuito produtivo da atividade agrária, pode ser analisada a partir das interações espaciais realizadas antes da unidade produtiva (Antes da porteira - cuja base territorial é a cidade). Dentro da unidade produtiva (Na porteira - cuja base territorial é o campo). Pós unidade produtiva Antes da unidade produtiva (Pós-Porteira). (ARRUDA, 2007: 27)

O modelo de agricultura capitalista hegemônico se reproduz no campo e na cidade e, para tanto, o modo de produção solda a cidade e o campo em uma unidade dialética, pois:

Com relação aos processos contraditórios e desiguais do capitalismo, devemos entender que eles têm se desenvolvido no sentido de ir eliminando a separação entre a cidade e o campo, entre o rural e urbano, unificando-os numa unidade dialética. (OLIVEIRA, 1991: 26)

Contudo, essa soldagem não elimina as diferenças entre cidade e campo, mas, ao contrário, as provoca (ALENTEJANO, 2003). Também:

O espaço rural e o espaço urbano serão concebidos como partes constitutivas de uma totalidade que se forma na diversidade. $O$ que se fará com base no conceito de divisão social do trabalho, considerando-se a influência da lei do desenvolvimento desigual e combinado. (MARQUES, 2002: 105)

Nossa concepção é de que a cidade e o campo constituem um território que se conecta com outros territórios por meio das relações de diferentes sujeitos, sejam econômicos ou sociais (LEMOS, 2008). Assim, o agronegócio não ocorre apenas no campo e, sim, no território, envolvendo o campo e a cidade.

De toda forma, o agronegócio não só intensifica as relaçães de base econômica entre o campo e a cidade, mas, ganha também, a dimensão das suas contradições sociais, resultantes do caráter concentrador de riqueza (principalmente de terra no campo) e produtor de miséria (no campo e na cidade).

Assim, entendemos que a utilização do termo Cidades do Agronegócio não permite a análise dos processos, contradições e conflitos de reprodução ampliada do capital no campo e na cidade 
promovida pela agricultura capitalista. Com efeito, elegemos o território (do capital) como conceito fundamental para compreendermos as contradições da reprodução do capital nas cidades especializadas no agronegócio.

\section{Sapezal (MT) e Chapadão do Sul (MS) no contexto do agronegócio: características e contradições}

Apresentando as contradições e características do que Elias (2003) denomina de "cidades do agronegócio", as cidades de Sapezal (MT) e Chapadão do Sul (MS), são exemplos de cidades especializadas na agricultura capitalista.

Idealizada por André Maggi e fundada em 1994, Sapezal (MT) (mapa 01), seu núcleo urbano foi projetado e construído para dar suporte ao agronegócio e à especulação imobiliária rural; enquanto Chapadão do Sul (MS), antes constituída por vasta área voltada para a prática agropecuária no município de Cassilândia (MS), posteriormente, com a compra de uma grande extensão de terra por Júlio Alves Martins, emancipou-se em 1987 para pleitear maiores investimentos do Estado.

Segundo Martins 6 (1996: 44):

Chapadão do Sul emerge como uma cidade "sem infância", uma cidade que nasceu adulta porque privada de espontaneidade, pois provida, em essência de uma racionalidade sem nenhum compromisso que não seja 0 da valorização das coisas pela desumanização do homem.

Estes municípios localizam-se em diferentes regiões. Sapezal (MT) está localizado ao Norte de Mato Grosso, na Microrregião Geográfica de Parecis ${ }^{7}$, microrregião que leva o nome de sua chapada, relevo propício para agricultura. Chapadão do Sul, como o próprio nome revela, localiza-se em região de chapada, no Nordeste de Mato Grosso do Sul, mais precisamente na Microrregião Geográfica de Cassilândia ${ }^{8}$ como apresenta o mapa 01.

\footnotetext{
${ }^{6}$ MARTINS, Sérgio. A cidade "sem infância:" a produção do espaço no mundo da mercadoria. Boletim Paulista de Geografia. São Paulo, 1996, 23-47 p.

${ }^{7}$ De acordo com o IBGE, esta microrregião é composta pelos municípios de: Campo Novo do Parecis, Campos de Júlio, Diamantino, Comodoro, Diamantino e Sapezal.

${ }^{8}$ De acordo com o IBGE, a Microrregião de Cassilândia: Cassilândia, Chapadão do Sul, Costa Rica e Paraíso das Águas.
} 
Mapa 01 - MT e MS: Municípios de Sapezal e Chapadão do Sul - localização

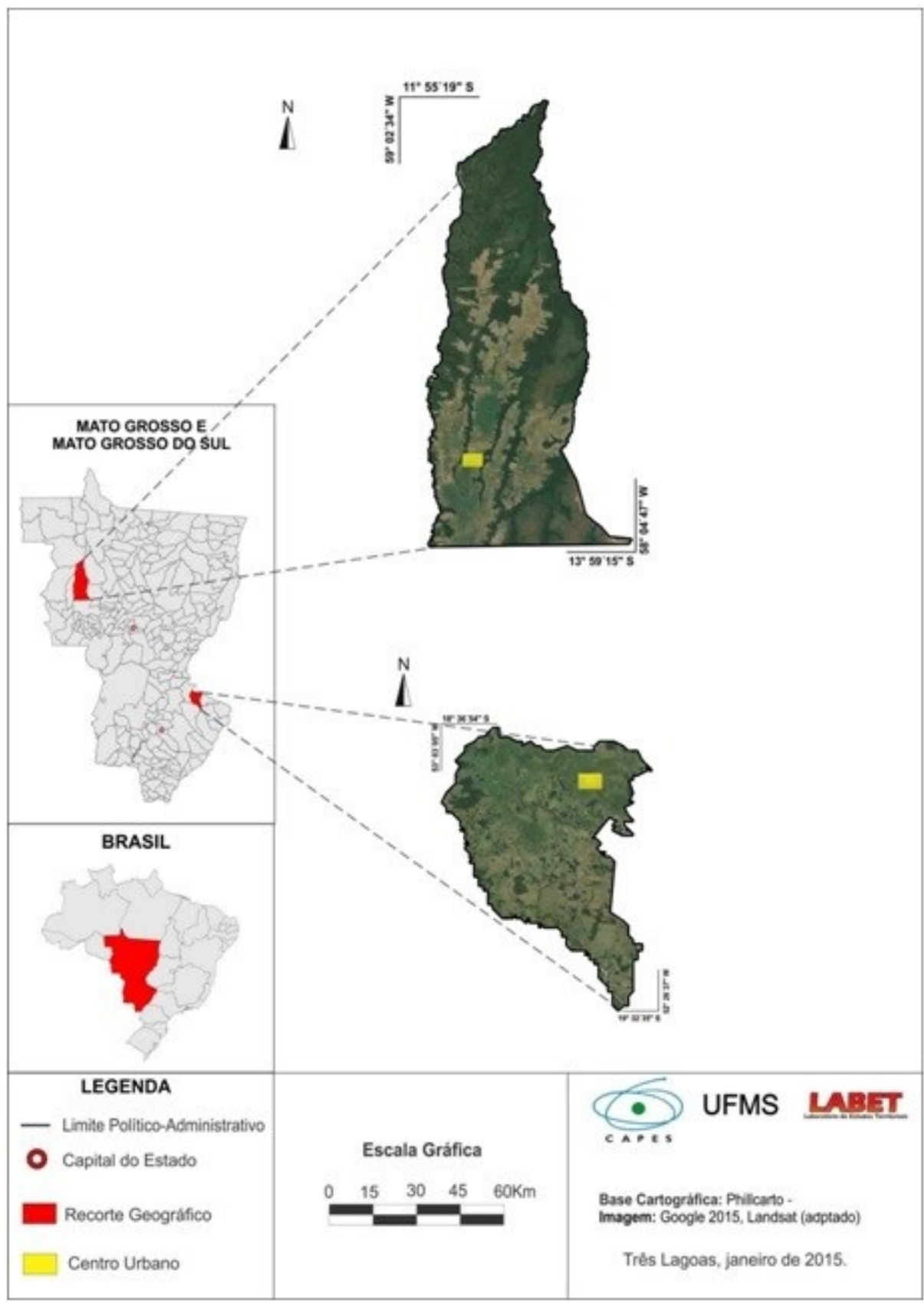

Organizado pelo autor.

As duas cidades emergiram do loteamento de áreas rurais. Em Chapadão do Sul (MS) 0 loteamento da futura cidade contou com intensas mediações políticas para instalação de prédios públicos, igrejas e associações. 
Foram doados terrenos para cada necessidade que ia surgindo como: escolas (estadual, Municipais, particular e creches), para os dois hospitais e Posto de Saúde, Correio, para diversas igrejas, delegacia de polícia, biblioteca, câmara municipal, destacamento militar, prefeitura, Clube Paineira, CTG (Centro de Tradição Gaúcha) e fórum. (ROCHA, 2005: 80)

Em Sapezal (MT), foram doados lotes por André Maggi a todos aqueles que, de alguma forma, contribuiriam ao funcionamento da cidade, do ponto de vista do crescimento econômico. Tal fato constitui certa homogeneidade no alto padrão de muitas moradias e, por outro lado, um grande número de trabalhadores não especializados à procura de emprego migrou (e migra) para o município. Esse contingente fica refém da especulação imobiliária, por isso se instalam em bairros periféricos com infraestrutura precária.

A cidade em si, como relação social e como materialidade, torna-se criadora de pobreza, tanto pelo modelo socioeconômico de que é suporte como por sua estrutura física, que faz dos habitantes das periferias (e dos cortiços) pessoas ainda mais pobres. (SANTOS, 1996: 10 - 11)

Com população de 18.094, no Censo Demográfico de 2010, Sapezal recebeu, até 2010, 17.971 migrantes, sendo que, desses, os fluxos advêm da região Centro-Oeste (11.025), Sul (3.205), Nordeste (2.023), Norte (935) e Sudeste (783). Chapadão do Sul possuía, em 2010, segundo o IBGE, 19.648 habitantes, destes, 10.137 são migrantes da região Centro-Oeste, 4.282 do Sul, 2.903 do Sudeste e 1.937 do Nordeste.

Durante trabalho de campo observamos que em Sapezal, a mão de obra sulista é predominantemente especializada e ocupa os melhores cargos, já os nordestinos compõem a mão de obra utilizada na produção de soja, milho e algodão, e no armazenamento e escoamento da produção.

A população destes dois municípios é predominantemente composta por migrantes à procura por trabalho, logo a relação entre a população e o município é estritamente econômica (MARTINS, 1996), (ARRUDA, 2007). Realidade, fruto da imagem da cidade "vendida" como local de sucesso financeiro e pessoal.

Moradora de Sapezal há doze anos, a migrante do Estado do Maranhão a procura de emprego, relata $^{9}$ a existência de um discurso sedutor espalhando a ideia das boas oportunidades de trabalho e de vida em Sapezal. Todavia, a realidade é outra, uma vez que a valorização do espaço impõe o custo de vida alto:

\footnotetext{
${ }^{9}$ Entrevista concedida durante trabalho de campo em novembro de 2013, na cidade de Sapezal (MT).
} 
Aqui tem muitas [pessoas] que vem pra cá através de outras pessoas, aí vem o pessoal chega lá fala assim: lá é bom de serviço, lá a cidade é rica! Quando chega aqui ai vai saber o sofrimento. Casinha desse tamanho aqui a gente paga 500, 600 reais. Uma casa bonita dessas daí, tem casa de até 3.000 reais 0 aluguel [...]. As pessoas pensam que aqui é bom, é bom pra trabalhar, pra serviço é bom, mas só o custo de vida, que é o que eu to falando para vocês. (Entrevistada A)

O relato da moradora desnuda a trama na vinda de trabalhadores para o município vislumbrando a oportunidade de emprego, contudo, são imensas as dificuldades para a permanência com dignidade. A moradora revela o preço pago pelo aluguel de pequenas casas num bairro popular chegava a um salário mínimo ${ }^{10}$.

Bem aqui assim [acenando], você vai nessa rua aqui tem três condomínios, que fizeram agora, é um salário, duas peças com um banheiro dentro. É um salário, o aluguel aqui não é baratinho não, ainda paga água, luz. (Entrevistada A)

O bairro popular compõe-se de casas pequenas e simples, com infraestrutura precária como apresentada nas figuras 1 e 2. A desigualdade social engendrada em Sapezal e Chapadão do Sul expressa-se na segregação socioespacial, pois os trabalhadores especializados residem em áreas centrais e os migrantes, não especializados e com baixos salários, nas periferias.

Figura 01 - Sapezal (MT): casa popular

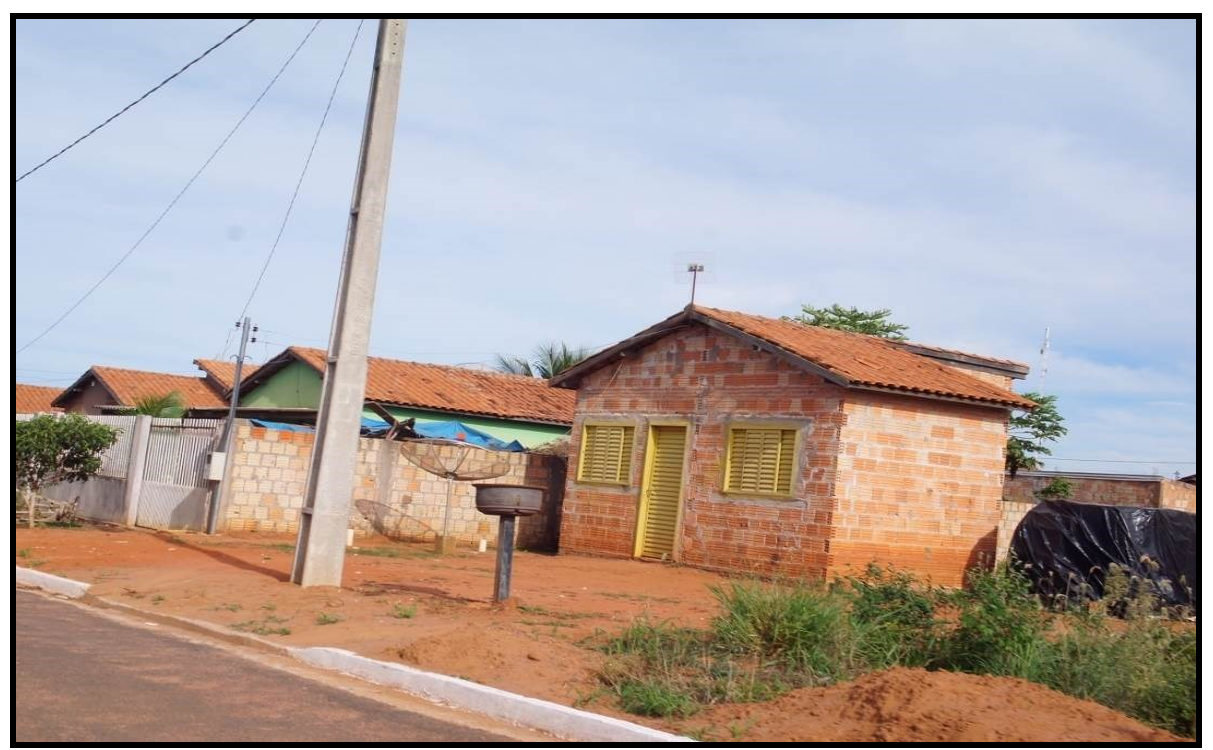

Fonte: Trabalho de campo em novembro de 2013.

$10 \mathrm{R} \$ 678,00$, à época. 
Figura 02 - Chapadão do Sul (MS): vista parcial do bairro popular

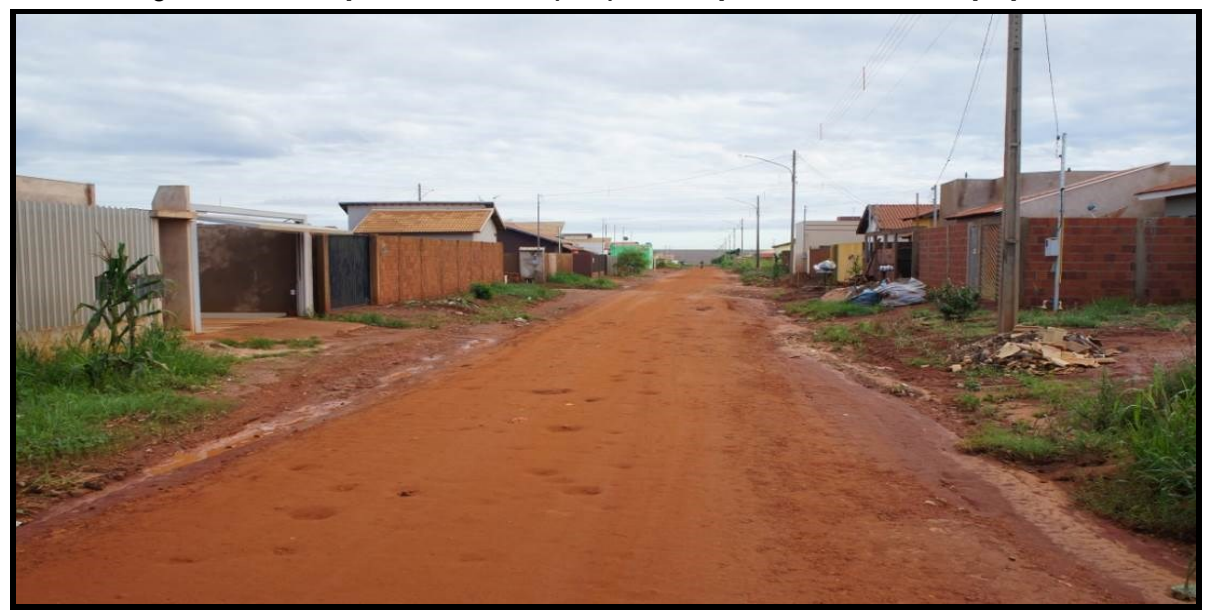

Fonte: Trabalho de campo em dezembro de 2014.

Em contraposição, as casas localizadas nos bairros centrais são a materialização da concentração de renda resultante de processos socioeconômicos, entre eles o desenvolvimento da agricultura capitalista, evidenciando o desenvolvimento econômico sem divisão da riqueza, reproduzindo e aprofundando as desigualdades sociais.

Figura 03 - Sapezal (MT): casa de alto padrão

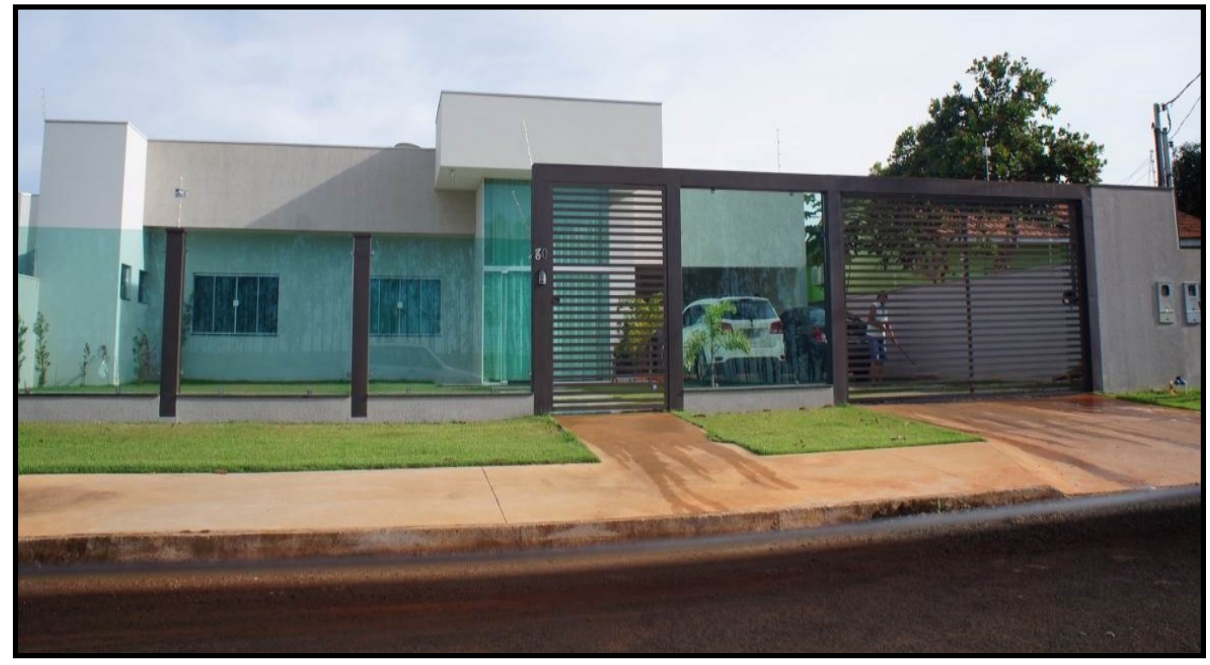

Fonte: Trabalho de campo em novembro de 2013. 
Figura 04 - Chapadão do Sul (MS): casa de alto padrão

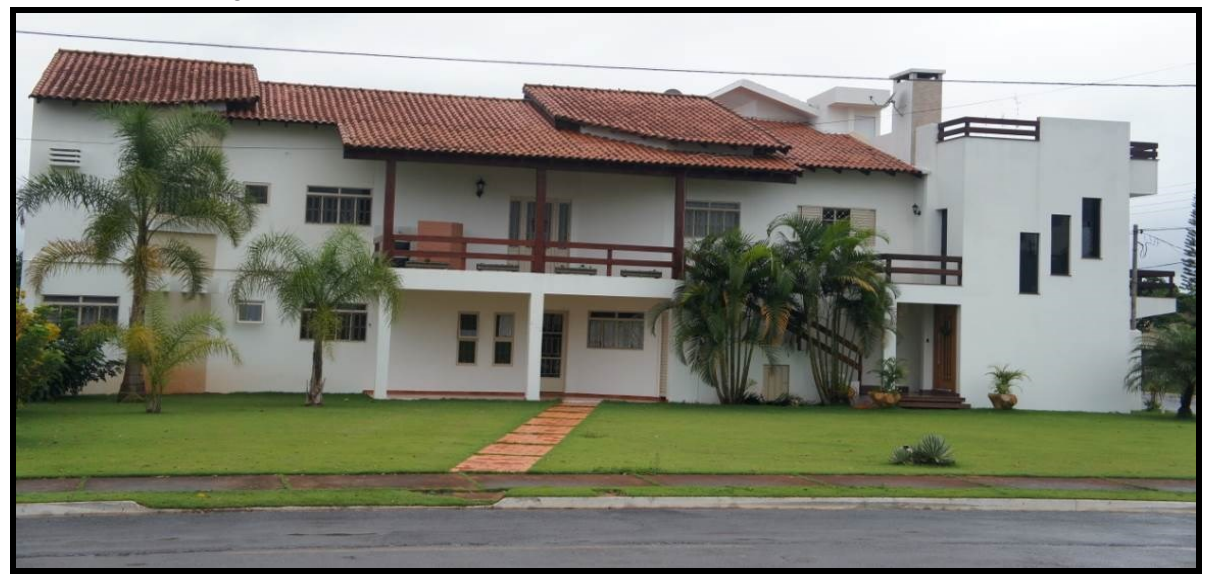

Fonte: Trabalho de campo em dezembro de 2014.

A segregação socioespacial é expressão das contradições presentes na organização das cidades, em outras palavras, "a segregação é uma forma de exclusão social que apresenta uma dimensão espacial" (VILLAÇA, 2003: 1). Ela não se apresenta apenas na diferenciação entre as moradias, mas de acesso aos serviços públicos, entre outros:

A segregação sócio-espacial assim definida não pode ser compreendida apenas pela diferenciação e isolamento espacial da função habitacional, mas pelas dificuldades de ter acesso ao conjunto da cidade, tanto no sentido objetivo, para aqueles que enfrentam as limitações orçamentárias para 0 acesso às formas mais eficientes de deslocamento e comunicação, como no sentido subjetivo, tendo em vista as dificuldades de construção coletiva de uma identidade urbana. (BELTRÃO SPOSITO, 1996: 82 - 83)

O agronegócio é a principal fonte de riqueza dos municípios de Sapezal e Chapadão do Sul e, ao mesmo tempo, o cerne da desigualdade social. Sapezal figura entre os maiores produtores de grãos do Brasil, produzindo, em 200611, 602.884 toneladas de soja e 320.362 toneladas de milho, e conta com a presença das principais empresas de produção e venda do mundo no setor (CARGIL, LOUIS DREYFUS e GRUPO MAGGI). A Avenida André Maggi, paralela à rodovia MT-235, é estratégica para a produção, nela se instalaram os principais silos de armazenamento e beneficiamento de soja, assim como empresas de comercialização e venda de maquinários agrícolas (Figura 05).

\footnotetext{
${ }^{11}$ IBGE, Censo Agropecuário 2006.
} 
Figura 05 - Sapezal (MT): Placas de Empresas ligadas ao agronegócio

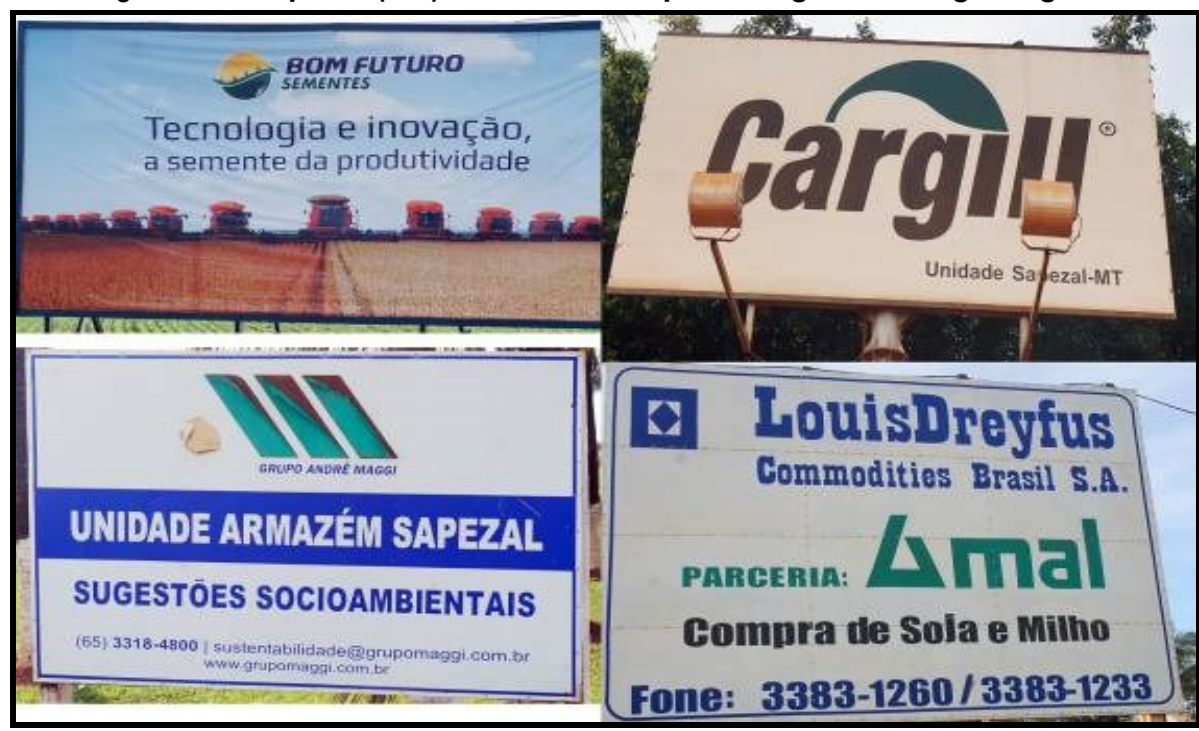

Fonte: Trabalho de campo em novembro de 2013.

A cidade de Chapadão do Sul estruturou-se em torno da rodovia MS-306, principal meio de escoamento da produção. Desta forma, na Avenida 2, paralela a rodovia estadual, estabeleceram-se empresas de comércio e serviços voltados à produção agrícola. O IBGE registrou no Censo Agropecuário, em 2006, a produção de 132.050 toneladas de soja e 99.030 toneladas de milho, em Chapadão do Sul. No entanto, ao contrário12 de Sapezal, a produção de grãos em Chapadão é feita e comercializada por associações de produtores (sulistas em sua grande maioria), com exceção da presença de silos da CARGILL.

${ }^{12}$ Cabe explicitar que Sapezal (MT) está localizado na principal região produtora de grãos do País (EMBRAPA), o que explica a atuação das principais empresas de produção e venda de grãos do mundo. Em Chapadão do Sul esse contexto é diferente, pois na região predomina a pecuária extensiva. 


\section{Figura 06 - Chapadão do Sul (MS): Placas de Empresas ligadas ao agronegócio}

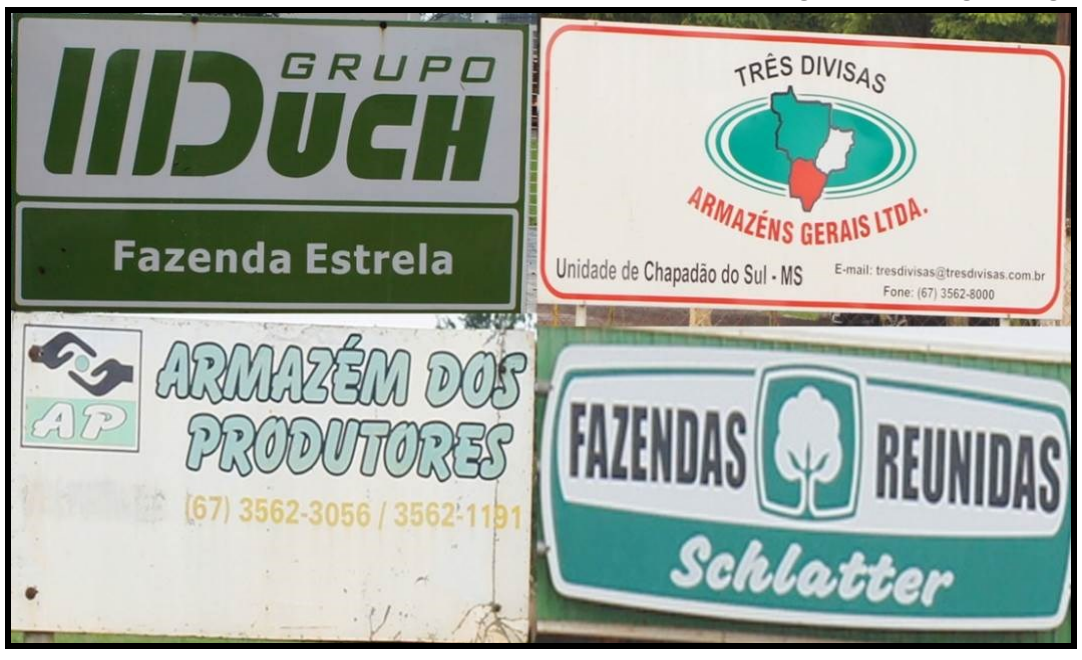

Fonte: Trabalho de campo em dezembro de 2014.

Outro diferencial em Chapadão do Sul está na educação, pois o município conta com o campus de Ciências Agrárias da Universidade Federal de Mato Grosso do Sul (UFMS), oferecendo cursos de graduação e pós-graduação em Agronomia e Engenharia Florestal.

Estas cidades refletem as contradições desse modelo produtivo, concentrador e excludente, gerando riqueza e miséria na cidade e no campo. O ônus desta opção à grande propriedade e produção de commodities é a inexpressiva produção de alimentos. A produção de alimentos em Sapezal é praticamente nula comparada à produção de soja e algodão, situação evidenciada pelos dados do censo agropecuário de 2006, conforme a tabela 03.

$\mathrm{Na}$ tabela 03, observa-se a produção do município, predominantemente, voltada para a produção de grãos (milho e soja) para a exportação e de algodão herbáceo. Em contrapartida, os alimentos presentes na mesa do brasileiro (arroz, feijão) não apresentam números de área colhida.

Tabela 03 - Sapezal (MT) - Área colhida (hectares) da lavoura temporária por produtos da lavoura temporária - 2006

\begin{tabular}{l|r}
\hline \multicolumn{1}{c|}{ Produtos da lavoura temporária } & \multicolumn{2}{c}{ Área colhida (ha) } \\
\hline Algodão herbáceo & 79.311 \\
\hline Arroz em casca & 0 \\
\hline Batata-inglesa & 0 \\
\hline Cana-de-açúcar & 0 \\
\hline Cebola & 0 \\
\hline Feijão preto em grão & 0 \\
\hline Feijão de cor em grão & 0 \\
\hline Feijão fradinho em grão & 0 \\
\hline Feijão verde & 0 \\
\hline Milho em grão & 320.362 \\
\hline
\end{tabular}




\begin{tabular}{l|lr}
\hline Soja em grão & 602.884 \\
\hline
\end{tabular}

Fonte: IBGE/SIDRA 2006. Organizado pelo autor.

O problema no abastecimento de alimentos apresentado pela tabela 03 levanta uma importante discussão sobre a opção pela agricultura capitalista mecanizada baseada na produção de commodities, em detrimento da agricultura camponesa ${ }^{13}$ produtora de alimentos. Sapezal (MT), nesse caso, depende da importação de alimentos de outros municípios e das poucas hortas urbanas produtoras de frutas. Hortaliças e leguminosas (mamão, abobrinha, alface, pimenta, entre outros). A figura 07 apresenta uma das principais hortas urbanas em Sapezal (MT).

Figura 07 - Sapezal (MT): Quitanda e horta urbana (ao fundo)

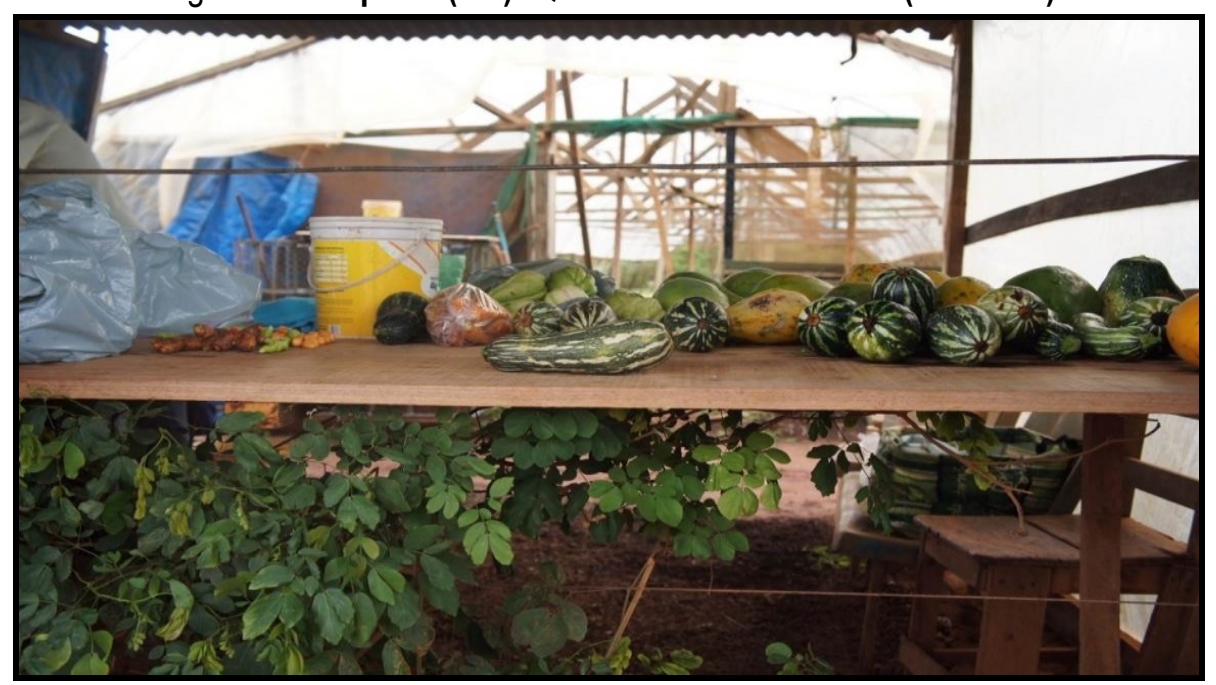

Fonte: Trabalho de campo em novembro de 2013.

Outra característica notada durante trabalho de campo em Sapezal está, segundo produtores na proximidade entre as hortas e as plantações de soja e algodão, sofrem com a pulverização. Segundo um dos produtores, a pulverização aérea prejudica a qualidade dos alimentos, pois o vento "leva" o agrotóxico até à horta e "queima" as frutas e hortaliças (figura 08).

${ }^{13}$ Compreendemos o campesinato como uma classe social dentro do capitalismo, resultado do desenvolvimento desigual, contraditório e combinado do capitalismo no campo (OLIVEIRA, 1991). 
Figura 08 - Sapezal (MT): Mamão atingido por pulverização

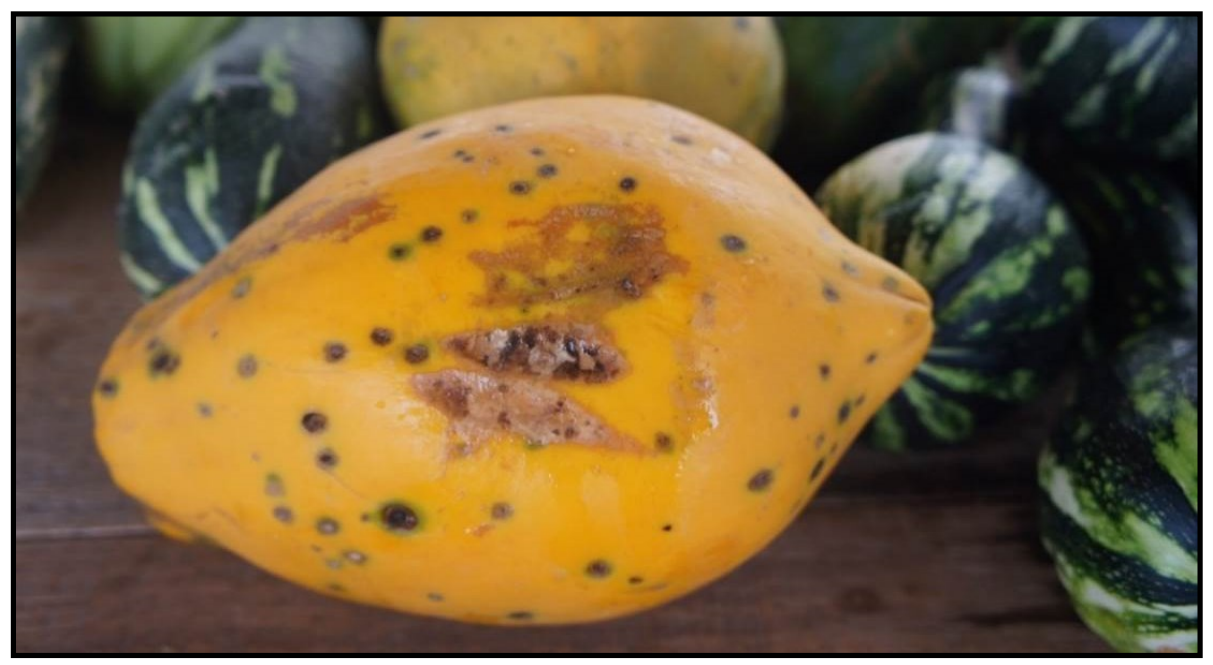

Fonte: Trabalho de campo em novembro de 2013.

Não é possível afirmar que há de fato danos causados à saúde por alimentos contaminados por agrotóxicos em Sapezal.

Já os dados do IBGE alertam para a grande quantidade de agrotóxicos utilizados pela agricultura brasileira, considerando-se que cerca de $70 \%$ da área colhida no Brasil, em 2006, utilizou agrotóxicos na lavoura.

Rigotto (2011) acrescenta:

O Brasil é o país que mais consumiu estes produtos no mundo em 2008, ultrapassando sua própria marca em 2009. No último ano para os quais se tem dados, foram consumidas mais de 1 milhão de toneladas, o que corresponde a mais de $22 \mathrm{~kg}$ por hectare de lavoura, ou ainda cerca de 5,2 quilos de agrotóxicos por habitante. (RIGOTTO, 2011: 48)

Temos ainda a pesquisa de Palma (2011) revelando a contaminação do leite materno por agrotóxicos no município de Lucas do Rio Verde (MT):

Os dados apresentados e discutidos no presente trabalho mostram um problema de saúde pública, o qual trabalhadores e população vizinha a áreas de produção de soja, milho ou algodão se encontram em situação de vulnerabilidade, face aos efeitos nocivos dos agrotóxicos sobre a saúde humana. (PALMA, 2011: 85).

Além dos problemas de intoxicação pelo uso de agrotóxicos, Pires et al (2006) alerta para os altos índices de suicídios com a utilização de agrotóxicos em Mato Grosso do Sul. Por exemplo, entre 
os anos de 1992 e 2002, "foram registradas 1.355 notificações de intoxicação, sendo 506 tentativas de suicídio que levaram a 139 óbitos" (PIRES et al, 2005: 604).

Quando voltamos a análise para os dados do Censo Agropecuário de 2006 sobre Chapadão do Sul, observamos a produção essencialmente voltada para Algodão, Soja e Milho segundo a tabela 04. Com área colhida essencialmente de Algodão Herbáceo, Milho e Soja, o município não apresenta produção significante de alimentos tradicionais da mesa do brasileiro.

Tabela 04 - Chapadão do Sul - Área colhida (hectares) da lavoura temporária - 2006

\begin{tabular}{l|r}
\hline \multicolumn{1}{c|}{ Produtos da lavoura temporária } & \multicolumn{1}{|c}{ Área colhida (ha) } \\
\hline Algodão herbáceo & 5.488 \\
\hline Arroz em casca & 0 \\
\hline Aveia branca em grão & 0 \\
\hline Batata-inglesa & 0 \\
\hline Cana-de-açúcar & 0 \\
\hline Cebola & 0 \\
\hline Feijão preto em grão & 0 \\
\hline Feijão de cor em grão & 0 \\
\hline Feijão fradinho em grão & 0 \\
\hline Feijão verde & 0 \\
\hline Mandioca (aipim, macaxeira) & 4 \\
\hline Milho em grão & 14.610 \\
\hline Soja em grão & 46.016 \\
\hline
\end{tabular}

Fonte: IBGE/SIDRA 2006. Organizado pelo autor.

Para amenizar os problemas relacionados à inexpressiva produção de alimentos (tabela 04), a prefeitura de Chapadão do Sul, por meio de seus funcionários cultiva hortaliças na área urbana (figura 09). A produção é distribuída gratuitamente para a população, possivelmente este é um indício do problema de abastecimento no município. 
Figura 09 - Chapadão do Sul (MS): Horta urbana Municipal

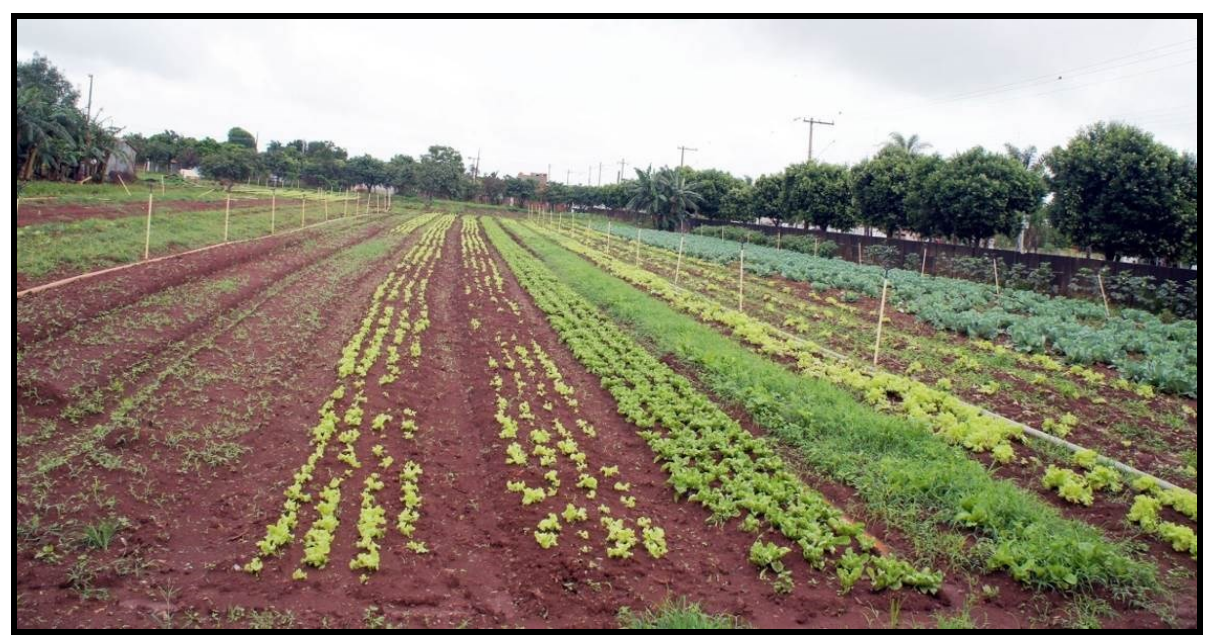

Fonte: Trabalho de campo em dezembro de 2014.

O caminho de superação desta tragédia é a soberania alimentar e a Agroecologia, bandeiras de luta dos movimentos socioterritoriais contra o agronegócio, mostrando a necessidade de acesso à alimentação de qualidade. Nesse sentido, a produção camponesa baseada no conhecimento popular sem a utilização de agrotóxicos é a alternativa para o atual modelo produtivo alicerçado na velha relação entre latifúndio e exportação.

Como dito, as estruturas fundiárias de Sapezal e Chapadão do Sul apresentam características similares, surgiram para dar apoio à comercialização de terras agrícolas. Desta maneira, os municípios apresentam concentração fundiária evidenciada pela tabela 05.

Sapezal apresenta estrutura fundiária extremamente concentrada, com 72 estabelecimentos ocupando $98,29 \%$ da área divididos em estabelecimentos com 1000 ou mais hectares. No entanto, se deve considerar como concentrada a estrutura fundiária deste município, pelo fato de apenas 87 estabelecimentos, concentrarem toda a área rural. Observa-se, ainda, a ausência de pequenas propriedades.

Em Chapadão do Sul a característica é semelhante, no qual, 92 estabelecimentos ocupam $81,64 \%$ da área total. Destacamos ainda que estes 92 estabelecimentos possuem área igual ou maior que 1000 hectares. 
Tabela 05 - Sapezal e Chapadão do Sul: número de estabelecimentos e Área dos estabelecimentos agropecuários por grupos de área total - 2006

\begin{tabular}{c|c|c|c|c}
\hline ANO & \multicolumn{2}{|c|}{ Sapezal } & \multicolumn{2}{c}{ Chapadão do Sul } \\
\hline Variável & $\begin{array}{c}\text { Estabeleci } \\
\text { mentos }\end{array}$ & Área \% & $\begin{array}{c}\text { Estabeleci } \\
\text { mentos }\end{array}$ & Área \% \\
\hline Menos de 10 ha & - & - & 96 & 0,12 \\
\hline 10 a menos de 100 ha & - & - & 141 & 1,68 \\
\hline 100 a menos de 1000 ha & 15 & 1,71 & 143 & 16,55 \\
\hline 1000 ha e mais & 72 & 98,29 & 92 & 81,64 \\
\hline
\end{tabular}

Fonte: IBGE/SIDRA. Organizado pelo autor.

A concentração fundiária é explicada pela demanda do agronegócio por grandes extensões de terra para a produção em larga escala, no caso de Sapezal e Chapadão do Sul, extensas fazendas de soja e milho. Esta característica da estrutura fundiária apresenta outra contradição, a inexpressiva presença de pequenos estabelecimentos agropecuários e, consequentemente da agricultura camponesa.

Esta contradição resulta em problemas no abastecimento de alimentos e na reprodução camponesa que em sua maioria migra para as cidades para vender sua força de trabalho ou, quando especializada, trabalha no agronegócio. Outra característica, segundo os dados do Banco de Dados da Luta pela Terra (DATALUTA) é a ausência de movimentos socioterritoriais que lutam pela terra realizando suas ações tanto no campo como na cidade.

\section{Considerações finais}

A dinâmica da agricultura capitalista nos estados de Mato Grosso e Mato Grosso do Sul produziu e produz intensas contradições como as apresentadas neste trabalho. As cidades de Sapezal (MT) e Chapadão do Sul (MS) evidenciam a organização da cidade para atender a produção do campo (agronegócio) e, contraditoriamente, espelha suas insustentabilidades.

Nestas cidades, há infraestrutura, com silos de armazenagem, empresas de produtos agrícolas e trabalhadores especializados. Contudo, as cidades, ao dependerem do agronegócio, se revelam vulneráveis a crises econômicas, como afirma ELIAS et al:

Cidades do agronegócio, tendem a ser os mais vulneráveis, uma vez que suas economias são altamente dependentes de um único setor produtivo, tornando-se os elos mais frágeis de circuitos espaciais produtivos de alcance mundial, cujo comando político encontra-se alhures. (2016: 268) 
Outra fragilidade está no abastecimento de alimentos, motivado pela falta de pequenos estabelecimentos responsáveis por este tipo de produção. Em seus relatos, moradores demonstraram preocupação com o uso intensivo de agrotóxico nos municípios, preocupação pertinente, uma vez que existam casos de contaminação em municípios dos estados de MT e MS, assim como pesquisas apontando problemas relacionados ao uso de agrotóxicos.

O campo, como parte do território capitalista apresenta forte concentração fundiária, resultado do processo de apropriação capitalista da terra. Os núcleos urbanos, criados com o objetivo de promover a venda de terras agricultáveis foram eficientes nesse processo. Desta maneira, a renda da terra é outro aspecto a ser considerado em futuras análises sobre as chamadas cidades do agronegócio.

Esse é o motivo pelo qual quando o capitalista comprar a terra não é porque esteja, como um senhor feudal, interessado na terra em si: o que ele efetivamente comprar é a renda da terra, o direito de se assenhorar de uma parte da mais-valia social. (MARTINS, 1981: 166)

Outra contradição constatada neste trabalho foi a segregação socioespacial expressada pelos problemas habitacionais nas cidades estudadas. Os relatos dos trabalhadores migrantes revelam problemas na qualidade de vida, infraestrutura e alto preço pago pelas moradias.

Este trabalho deve subsidiar as discussões e auxiliar a desmistificar o discurso do sucesso econômico e social nas chamadas cidades do agronegócio. Na realidade, estas cidades compõem um território do capital que se baseia na exploração do trabalho.

Convém dizer que o capitalismo está em expansão tanto no campo quanto na cidade, pois essa é a sua lei: a lei da reprodução crescente, ampliada. A tendência do capital é a de tomar conta progressivamente de todos os ramos e setores da produção, no campo e na cidade, na agricultura e na indústria. (MARTINS, 1981: 153)

Assim, com um olhar crítico foi possível observar os intensos problemas sociais nas cidades de Sapezal (MT) e Chapadão do Sul (MS) resultantes do desenvolvimento capitalismo no campo e na cidade. Desta maneira, concluímos que o conceito de território seja mais pertinente que o termo cidades do agronegócio.

Uma vez que o território pressupõe relações de poder, assim, cidades e o campo compõe um território hegemonicamente organizado para a reprodução do capital e que, reflete suas contradições. 


\section{Referências}

ABREU, Silvana de. Planejamento governamental: A SUDECO no espaço Mato-Grossense: contexto, propósitos e contradições. 323f. Tese (Doutorado em Geografia) - Faculdade de Filosofia, Letras e Ciências Humanas, Universidade de São Paulo. 2001.

ALENTEJANO, Paulo Roberto R. As relações campo-cidade no Brasil do século XXI. Terra Livre, São Paulo, v. 2, n. 21, p. 11-23, jul./dez. 2003.

ARRUDA, Zuleika A. Onde está o agro deste negócio? Transformações socioespaciais em Mato Grosso decorrentes do agronegócio. 257f. Tese (Doutorado em Geografia), UNICAMP, 2007.

BECKER, Bertha K. Amazônia. Série Princípios. São Paulo: Editora Ática, 1994.

BELTRÃO SPOSITO, Maria Encarnação. Reflexões sobre a natureza da segregação espacial nas cidades contemporâneas. Revista de Geografia. Dourados: AGB, 1996, p. 71-85.

BELTRÃO SPOSITO, Maria Encarnação. Capitalismo e Urbanização. 14 ed. São Paulo: Contexto, 2004.

ELIAS, D. Globalização e Agricultura. São Paulo: Editora Edusp, 2003.

ELIAS, D. Relações Campo-Cidade, Reestruturação Urbana e Regional no Brasil. In: XII Colóquio Internacional de Geocrítica. Anais. Bogotá: UNC: 2012. 16p.

ELIAS, D. Agronegócio e Novas Regionalizações no Brasil. In: Revista Brasileira de Estudos Regionais. V. 13, N. 2. Nov. 2012. 153-167p.

ELIAS, D. S. PEQUENO, L. R. B. Desigualdades socioespaciais nas cidades do agronegócio. Revista Brasileira de Estudos Urbanos e Regionais. Rio de Janeiro, v. 9, n. 1, p. 25-39, mai. 2007.

ELIAS, D. et al. Regiões do agronegócio, novas relações campo-cidade e reestruturação urbana. Revista da Associação Nacional de Pós-graduação e Pesquisa em Geografia (Anpege). p.265-288, V.12, n.18, 2016.

EMBRAPA - Empresa Brasileira de Pesquisa Agropecuária. Estatísticas - Soja. 2014.disponível em: $<$ <ttp://www.cnpso.embrapa.br/index.php?op_page=294\&cod_pai=16>. Acesso em 3 de ago 2014.

FABRINI, João E. ROOS, Djoni. Conflitos territoriais entre o campesinato e o agronegócio latifundiário. São Paulo: Editora Outras Expressões, 2014.

FREDERICO, Samuel. As cidades do agronegócio na fronteira agrícola moderna brasileira. Caderno Prudentino de Geografia, Presidente Prudente, n.33, v.1, p.5-23, jan./jul.2011.

GRAZIANO, José da Silva. A modernização dolorosa: estrutura agrária, fronteira agrícola e trabalhadores rurais no Brasil. Rio de Janeiro: Editora Zahar, 1982.

IANNI. Octavio. Colonização e contra-reforma Agrária na Amazônia. Petrópolis: Editora Vozes. 1979. INSTITUTO BRASILEIRO DE GEOGRAFIA E ESTATÍSTICA - IBGE. Censo Agropecuário, (SIDRA). Mato Grosso do Sul. Rio de Janeiro: IBGE, 1995/1996 e 2006.

INSTITUTO BRASILEIRO DE GEOGRAFIA E ESTATÍSTICA - IBGE. Comentários In: Censo Agropecuário $2006 . \quad$ Disponível em <http://www.ibge.gov.br/home/estatistica/economia/agropecuaria/censoagro/brasil_2006/comentarios.p df> Acesso em 19 jan. 2015.

INSTITUTO BRASILEIRO DE GEOGRAFIA E ESTATÍSTICA - IBGE. Relatório de Produção Agrícola Municipal

2010.

Disponível:<www.ibge.gov.br/home/estatistica/economia/pam/2010/PAM2010_Publicacao_completa.pd f> Acesso em: 20 jan. 2015.

INPE/CANASAT. Área de colheita de cana-de-açúcar nos Estados de MT e MS - Safras 2000/2012. Disponível em: <http://www.dsr.inpe.br/canasat/>. Acesso em: 14 mar. 2014.

LEITE, Sérgio, P. MEDEIROS, Leonilde. S de. Agronegócio. In: CALDART, R. PEREIRA, I. ALENTEjANO, P. FRIGOTTO,G. (Orgs.) Dicionário da Educação do Campo. São Paulo: Editora Expressão Popular, 2012.

LEMOS, Linovaldo, M. O global e o local numa lógica reticular. In: Revista de Economia Heterodoxa, nº 9, ano VII, 2008. 
MARCOS, V. Trabalho de campo em geografia: reflexões sobre uma experiência de pesquisa participante. Boletim Paulista de Geografia, São Paulo, nº 84, 2006, p. 105-136.

MARQUES, Marta Inez Medeiros. O conceito de espaço rural em questão. Terra Livre. São Paulo, Ano 18, n. 19, jul./dez. 2002.

MARGARIT, Eduardo. Tramas políticas e impactos socioambientais na Amazônia: a dinâmica do processo de pavimentação da BR-163. 146f. Dissertação (Mestrado em Geografia). UFMS. Três Lagoas. 2012.

MARTINS, José de Souza. Os camponeses e a política no Brasil. Petrópolis: Editora Vozes.1981.

MARTINS, José de Souza. O Cativeiro da Terra. São Paulo: Editora Ciências Humanas, 1986.

MARTINS, José de Souza. O poder do atraso. São Paulo: Editora Hucitec, 1994.

MARTINS, Sérgio. A cidade "sem infância:" aprodução do espaço no mundo da mercadoria. Boletim Paulista de Geografia. São Paulo, 1996, p. 23-47.

MELO, Danilo S. NARDOQUE, Sedeval. As manifestações em Mato Grosso do Sul e a relação campocidade. Boletim DATALUTA. NERA. Presidente Prudente. Jan 2014. 10 p. 131.

MORENO, Gislaene. Os (Des) Caminhos da Apropriação Capitalista da terra em Mato Grosso. $633 \mathrm{f}$. Tese de Doutorado. FFLCH USP. São Paulo. 1994.

MORENO, Gislaene. Terra e Poder em Mato Grosso: política e mecanismos de burla (1892-1992). Cuiabá, MT: Entrelinhas/EdUFMT, 2008.

MOTTA, Regina Célia C. de S. As linhas da campesinidade na (in)subordinação camponesa em Glória de Dourados - MS. 244f. Dissertação (Mestrado em Geografia) - Universidade Federal da Grande Dourados. 2013.

NAGLIS, Suzana G. Batista. Marquei aquele lugar com o suor do meu rosto": os colonos da Colônia Agrícola Nacional de Dourados - CAND (1943-1960). 118f. Dissertação (Mestrado em História) UFGD, Dourados. 2007.

OLIVEIRA, Ariovaldo Umbelino de. A agricultura camponesa no Brasil. São Paulo: Editora Contexto, 1991.

OLIVEIRA, Ariovaldo Umbelino de. A geografia das lutas no campo. São Paulo: Editora Contexto, 1994.

OLIVEIRA, Ariovaldo Umbelino de. A Longa Marcha do campesinato brasileiro: movimentos sociais, conflitos e Reforma Agrária. Estudos Avançados. Vol. 15 n. 43 - São Paulo, Sept/ Dec. 2001.

OLIVEIRA, Ariovaldo Umbelino de. Agricultura e indústria no Brasil. campo-território, v.5, n.10, p. 5-64, ago. 2010.

OLIVEIRA, Ariovaldo Umbelino de. A mundialização da agricultura brasileira. Actas XII Colóquios de Geocrítica. http://www.ub.edu/geocrit/coloquio2012/actas/14-A-Oliveira.pdf, 2012. Acesso em 22 fev. 2014.

PALMA, Danielly Cristina de A. Agrotóxicos em leite humano de mães residentes em Lucas do Rio Verde - MT. 104f. Dissertação de mestrado (Mestrado em saúde). UFMT. Cuiabá. 2011.

PEREIRA, Mônica C. de B. Revolução Verde. (In) CALDART, Roseli Salete; PEREIRA, Isabel Brasil; ALENTEJANO, Paulo; FRIGOTTO, Gaudêncio (orgs.). Dicionário da Educação do Campo. Editora Expressão Popular, 2012.

PICOLI, Fiorelo. O Capital e a devastação da Amazônia. São Paulo: Expressão Popular, 2006.

PIRES, Dario, X. Et al. Uso de agrotóxicos e suicídios no Estado do Mato Grosso do Sul, Brasil. Cad. Saúde Pública, Rio de Janeiro, mar./abr, 2005, p 598-605.

PORTO-GONÇALVES, Carlos Walter. A Globalização da Natureza e a Natureza da Globalização. Rio de Janeiro: Editora Civilização Brasileira, 2006.

PORTO-GONÇALVES, Carlos Walter. A geografia da riqueza, fome e meio ambiente. In: OLIVEIRA, A. U.; MARQUES, M. I. M. (Orgs.). O campo no século XXI. São Paulo: Editora Casa Amarela e Editora Paz e Terra, 2004, p.207-253. 
RIGOTTO, Raquel. O uso seguro de agrotóxicos é possível? In: LONDRES, Flávia. Agrotóxicos no Brasil: um guia para ação em defesa da vida. Rio de Janeiro: AS-PTA - Assessoria e Serviços a Projetos em Agricultura Alternativa, 2011, p. 48-51. 133p.

ROCHA, Jonas R. da. Chapadão do Sul (MS): um espaço construído no contexto da soja. $137 f$. (Dissertação Mestrado) Universidade Federal de Uberlândia. Uberlândia. 2005.

SANTOS, Milton. Urbanização Brasileira. São Paulo: Editora Edusp, 1996.

SANTOS, Milton. Sociedade e espaço: a formação social como teoria e como método. In: SANTOS, Milton. Da totalidade ao lugar. São Paulo: Editora EDUSP, 2012. p.21-41.

SILVA, S. C. A família de municípios do agronegócio: expressão da especialização produtiva no front agrícola. 129f. (Dissertação Mestrado). Campinas, 2007.

VILLAÇA, Flávio. A segregação urbana e a justiça (ou a justiça no injusto espaço urbano). Revista Brasileira de Ciências Criminais. São Paulo, Brasil: Revista dos Tribunais, v.11, n.44, jul./set. 2003, p. 341-346.

(Recebido em 21-06-2016; Aceito em: 12-07-2016) 